\title{
INFLUENCING THE PRACTICE OF HUMAN RESOURCE ACCOUNTING: SKILLS AND STRATEGIES
}

\author{
DOI: 10.17261/Pressacademia.2017.443 \\ JEFA-V.4-ISS.2-2017(8)-p.138-144
}

\section{Krishna Priya Rolla ${ }^{1}$}

${ }^{1}$ Dr. Babasaheb Ambedkar Marathwada University, Aurangabad, India. rkpriya.mgtsci@bamu.ac.in

\section{To cite this document}

Rolla, K.P., (2017). Influencing the practice of human resource accounting: skills and strategies. Journal of Economics, Finance and Accounting (JEFA), V.4, Iss.2, p.138-144.

Permemant link to this document: $\mathrm{http}: / /$ doi.org/10.17261/Pressacademia.2017.443

Copyright: Published by PressAcademia and limited licenced re-use rights only.

\section{ABSTRACT}

Purpose- The purpose of the study is to provide empirical insights into the relationship between the prevalence of human resource accounting with skill inventory existent in an organization. Valuing human resources is argued to be one of the key elements of strategic human resource management. This argument has been widely advocated by empirical research, especially by studies executed in developed countries.

Methodology- The purpose of the study is to provide empirical insights into the relationship between the prevalence of human resource accounting (HRA) with skill inventory in the particular context of Indian manufacturing sector. The sample comprises of ninety-six India manufacturing units (Israel 1992). The data is collected by survey-study using established and validated scales in the international context. The author has used a two-step data analysis - factor and regression analysis - to answer research questions.

Findings- The findings demonstrate significant positive relationship between HRA as independent variable and endogenous variables: Business, Technical and Strategic Human Resource Management Skills.

Conclusion- The study implicates need for enhanced skill-inventory and human resource investments. The study contributes to further development of HRA in developing countries, especially in institutional and cultural contexts of India.
\end{abstract}

Keywords: Human resource accounting, skill inventory, India.

JEL Codes: G10, M21

\section{INTRODUCTION}

With the tectonic shift in market dynamics, the twenty-first century has summoned intangible assets as the value creators (Sveiby K. E., 1997) (Edvinsson \& Malone, 1997). Human resources and the assets that emancipate from them have received special consideration in the past few decades. Penrose argued that the heterogeneity of competencies embedded in an organization, gives each firm its unique essence for strategic advantage (Penrose, 1959). Assets like knowledge, skills, emotions, culture, ability to innovate etc. have been granted impetus, in the recent past. Thus conclusively indicate that the competence of the human resource departments, determine the ability of the organization to mint revenue and sustain in the knowledge economy.

Equally significant is the question, whether these market mandates are true for the emerging markets? Is human resource as assets is equally significant for the emerging economies? India as an economy has witnessed one of the highest growths in 1998; which were termed to be newly industrializing countries in the 1980, which was applied to fast-growing and 
liberalizing Asian and Latin American countries. The term newly industrialized countries, has been replaced by a broader term called emerging market economies. An emerging economy can be defined as a country that satisfies two criteria: a rapid pace of economic development and government policies favoring economic liberalization and adoption of freemarket system (Arnold \& Quelch, 1998). Thus, India with its economic development and liberalized economy, can be said to be one of the fast progressing economies.

Table 1: Economic Development of BRIC

\begin{tabular}{|c|c|c|c|c|c|c|c|c|c|}
\hline \multirow[t]{2}{*}{ Country } & \multirow{2}{*}{$\begin{array}{c}2015 \text { GDP } \\
\text { (trillion US\$) }\end{array}$} & \multirow{2}{*}{$\begin{array}{l}2015 \text { GNI } \\
\text { (US\$) }\end{array}$} & \multicolumn{2}{|c|}{ Growth in GNI } & \multicolumn{2}{|c|}{ Inflation } & \multicolumn{2}{|c|}{$\begin{array}{c}\text { Service as a \% } \\
\text { of GDP }\end{array}$} & \multirow{2}{*}{$\begin{array}{r}\text { FDI as a \% of } \\
2016 \text { GDP }\end{array}$} \\
\hline & & & 2010 & 2015 & 2010 & 2016 & 1995 & 2014 & \\
\hline dia & 2.074 & 1.590 & 1150 & 1590 & 5.4 & 1.6 & 46.3 & 52.6 & $44,208,019,072$ \\
\hline azil & 1.774 & 9.850 & 9650 & 9850 & 5.0 & 9.0 & 66.7 & 70.8 & $75,074,564,670$ \\
\hline r & 1.326 & 11.400 & 9230 & 11400 & 6.8 & 15.5 & 55.9 & 63.7 & $4,838,600,000$ \\
\hline na & 10.866 & 7.820 & 3650 & 7820 & 3.3 & 1.4 & 33.7 & 48.1 & $249,858,920,111$ \\
\hline
\end{tabular}

Gross Domestic Product that forms to be an indicator of organizational success, it could be found that India has swiftly shifted itself to be a service-oriented economy. This service-intensive economy has to its core, human as the significant element of those operations. Hence, it becomes significant as part of the research quest, to investigate and establish the extent of human significance in the growth of those organizations. Research in organizational psychology mandates investigation into human resources can yield positive organizational performance and allied outcomes (Becker, Huselid, \& Ulrich, 2001) (Huselid, 1995) (Kaplan \& Norton, 1996) (Grant, 1991). Hence one of the key elements of an organizational investigation should be potentially based on ingredients of what modulates their performance to contribute to organizational success.

The proponents of resource-based theory, thus limelight the role of human capital as a key factor explaining why some firms outperforms the rest (Acedo, Barroso, \& Galan, 2006) (Barney, Firm resources and sustained competitive advantage, 1991) (Barney, 2001) (Barney \& Arikan, 2001). It argues that the constitution of heterogeneous distribution of valuable resources amongst firms; especially the diversity enshrined in human resources, bestows strategic advantage and performance outcomes, to any organization. This doctrine was strengthening by the convergence of knowledge embedded in human capital as the most ubiquitously valuable, and inimitable resource (Kogut \& Zander, 1992) (Grant, Prospering in dynamically competitive environments: Organizational capability as knowledge integration, 1996). Resource-based theorists have established the synchronization of human resources with organizational performance and sustained strategic advantage (Barney, 2001). Further its relevance in contextual and micro studies is granting it the merit for omnipresence (Gong, Law, Chang, \& Xin, 2009) (Takeuchi, Lepak, Wang, \& Takeuchi, 2007) (Tatiana \& Tatiana, 2000).

\section{ELEMENTS OF HUMAN RESOURCE ACCOUNTING}

The research on human resource accounting intensified in 1960s and withered in the later half of the century. Research studies have focused on issues related to viability of the human valuation to be usable in industry (Likert, 1967; Brummet, Falmholtz, \& Pyle, 1969; Cascio W. F., 1992; Lezotte, Raju, Burke, \& Normand, 1996) and how to report human resource accounting on balance sheet (Dobija, 1998; Epstein \& Manzoni, 1997; Flamholtz E. , 1972; Hedlin \& Adolphson, 2000; Hekimian \& Curtis, 1967).

\subsection{People's Department Composition, Talent Acquisition}

The works of Sveiby that he termed as intangible assets, worked on indicators like growth, renewal, efficiency and stability. His approach stressed on measuring the intangible assets like employee competence, internal structure, intellectual capitals, relationship with customers (its value) etc. The model indicated measurement of employee worth by the number of years in the profession, education levels, training costs etc. The study also indicated that ratios of professionals to total organizational headcount, leveraging profit per professional, value-added per employee, efficiency of employees etc. can be considered as significant indicators to ascertain the organizational financial health. The study also proposed indicators like age, experience, seniority, time with current job and turnover measures as indices to progress with the study (Sveiby K. B., 1997). The significance of indices for human resource accounting was explored in the context of civil aviation at The Swedish National Telecommunications Company. The study revealed that organization reported the HR income statement, balance sheet, with a mention of the percent of value of human capital, headcount and the calculated value of these indices as a reliable measure (Telia, 1996). Categorical studies documented on the presence of human value measurement in various organizations. The study also indicated a significant relationship between the ratio of 'intellectual resources' to the number of employees in human resource department, as an indicator for organizational health. Synchronously Likert also argues on the measurement of human value as influenced by skill set amongst the functional experts in the organization. Thus proposing ways to measure skill-set (Likert, 1967). 


\subsection{Application for Indian Contextual Study}

The role of human resource accounting (and its determinants) for organization - wide acceptability has received exhaustive focus in the American (Brummet, Falmholtz, \& Pyle, 1969), Norwegian (Sandervang, 2000), British (Morrow, 1996), Irish (O'Regan, O'Donell, Kennedy, Bontis, \& Cleary, 2001), Finnish (Vuontisjarvi, 2006) and other international contexts. Petite has been studied on the prevalence of HRA in Indian context. The native research fraternity is entrusted with the responsibility to define, contextualize, design, measure, develop and implement human accounting models.

Another macro intervention was initiated to understand the HRA disclosures made in the financial statements in six countries. The study analyzed the differences of disclosures made in the annual reports of USA, Canada, Japan, England, Germany and South Korea (Subbarao \& Zehgal, 1997). Barring a few studies, there has been very little empirical work in Indian corporate scene on human resource accounting (Sur \& Jafar, 2008; Srimannarayana, 2009; Sirisetti \& H; Kashive N. , 2010; Sharma \& Shukla, 2010). Another research study tried to identify and observe the extent of HRA practice; and concluded that it was only restricted to a mere $1 \%$ (for the selected sample), with no much inter-sample uniformity in their observance (Kaur, Venkat Raman, \& Singhania, 2014). The study was crucial, as to identify that there lies a lack of framework for observing HRA and hence a dire need to prescribe and present a framework. A case study that followed, also reiterated the need for a proper structure, as the study witnessed subjectivity in the reporting styles of four prestigious companies in India (Shah \& Khedkar, 2006; Dalwadi, 2010; Joshi \& Mahel, 2012). In the wake of such ambiguity, a study suggested that there was a growing trend of reporting HRA in India, especially in Public Sector Undertakings of India. Further, Lev and Schwartz Model is the most popular reference for computation (with their own customizations) and at the same time, there is also a growing indication of stoppage of reporting of HRA by certain companies (Narayanankutty, 2012). In sync with these findings, there was another study that also surface a concern that inspite of reporting HRA in the balance-sheets, yet there was no mention being made in the books of accounts by those respective organizations (Sonara, 2009). Finally, the most recent study that benchmarked human resource accounting methods of India with its foreign contemporaries like Skandia - Navigator; revealed a retarded native progression in the field (Kashive, 2013).

\section{HYPOTHESIS}

Based on the literature review and established theoretical constructs, the current study establishes the following hypothesis, which is further processed for statistical significance:

H1: $\quad$ Prevalence of human resource accounting practices has strong correlation with the ratio of HR professionals to the headcount of an organization.

H2: $\quad$ Prevalence of human resource accounting practices exhibits relationship with the business skill-set in the human resource departments.

\section{METHOD}

\subsection{Sample}

The objective of the study was to collect the data that examined the significance of human resource quantification to their respective organization. The sample constituted a total of ninety six manufacturing units in India (Israel, 1992). The data was collected by survey-study with proven and established scales in the international milieu. Each of these ninety-six samples qualified to be in sample; by being a large-scale manufacturing industry i.e. they qualified to be a manufacturing enterprise where the investment in plant and machinery (excluding land and buildings) is more than 100 million rupees.

\subsection{Design}

The questionnaire was administered and received back from a total of ninety-six organizations, out of which ninety-one were considered for statistical analysis. The rest were discarded, either due to incomplete data, presence of outliers that skewed the data, and when the feedback was in stark contradiction to the established theoretical constructs.

The study was preceded with a pilot study, to further contextually validate the research tool (for India); which exhibited an internal-consistency index (Cronbach) $\alpha$ of 0.62 ; following which the tool was administered to rest of the sample-size.

\subsection{Limitations}

The study exhibits limitations of geographically relevant, which may not propel the same relationship in other contextual studies. The study has also constraint of time and 140atüre of industries (manufacturing organizations) that may have also exerted a certain degree of distortion on the generation of theory. 


\section{DATA ANALYSIS}

The study resorted to drawing inferences from correlation matrix, followed by regression coefficient that was further processed for derive inferences. Certain aspects of the analysis, failed to find statistical significance with certain variables that are discussed as part of the study, but still were omitted in the following discussion.

The statistical analysis could be represented as follows:

Table 2: Correlation Statistics of the Model

\begin{tabular}{|c|c|c|c|c|c|c|}
\hline & 1 & 2 & 3 & 4 & 5 & 6 \\
\hline \multicolumn{7}{|l|}{ HRDHeadC } \\
\hline OrgHeadC & $\begin{array}{l}0.758^{*} \\
0.001\end{array}$ & & & & & \\
\hline T\&DBudg & $\begin{array}{l}-0.109 \\
0.749\end{array}$ & $\begin{array}{l}-0.110 \\
0.746\end{array}$ & & & & \\
\hline ProfHRCap & $\begin{array}{l}-0.210 \\
0.472\end{array}$ & $\begin{array}{l}0.067 \\
0.820\end{array}$ & $\begin{array}{l}0.018 \\
0.961\end{array}$ & & & \\
\hline StratHRCap & $\begin{array}{l}0.649^{+} \\
0.012\end{array}$ & $\begin{array}{c}-0.447 \\
0.109\end{array}$ & $\begin{array}{l}0.031 \\
0.933\end{array}$ & $\begin{array}{c}0.704^{* *} \\
0.005\end{array}$ & & \\
\hline TechHRCap & $\begin{array}{l}-0.398 \\
0.159\end{array}$ & $\begin{array}{c}-0.167 \\
0.568\end{array}$ & $\begin{array}{l}-0.152 \\
0.675\end{array}$ & $\begin{array}{l}0.883^{*} \\
0.000\end{array}$ & $\begin{array}{c}0.806 * \\
0.001\end{array}$ & \\
\hline BussHRCap & $\begin{array}{l}-0.254 \\
0.380\end{array}$ & $\begin{array}{l}0.166 \\
0.570\end{array}$ & $\begin{array}{l}-0.080 \\
0.827\end{array}$ & $\begin{array}{c}0.753^{* *} \\
0.002\end{array}$ & $\begin{array}{c}0.681 * * * \\
0.007\end{array}$ & $\begin{array}{r}0.782^{*} \\
0.001\end{array}$ \\
\hline Cell Contents: & \multicolumn{6}{|c|}{$\begin{array}{l}\text { Pearson correlation } \\
\text { P-Value }\end{array}$} \\
\hline \multicolumn{7}{|c|}{ Significance - $\quad{ }^{*} \mathrm{p}<0.01, * * \mathrm{p}<0.05, * * * \mathrm{p}<0.10$} \\
\hline $\begin{array}{l}\text { HRHeadC - HR } \\
\text { OrgHeadC - Or } \\
\text { T\&DBudg - Tra } \\
\text { ProfHRCap - P } \\
\text { StratHRCap - S } \\
\text { TechHRCap - T } \\
\text { BussHRCap - B }\end{array}$ & $\begin{array}{l}\text { artment H } \\
\text { zation-wic } \\
\text { g and Dev } \\
\text { ssional HR } \\
\text { egic HR Ca } \\
\text { hical HR Cá } \\
\text { ess HR Ca }\end{array}$ & $\begin{array}{l}\text { ount / Tc } \\
\text { t Budget } \\
\text { ties / Skil } \\
\text { s }\end{array}$ & power & & & \\
\hline
\end{tabular}

\subsection{Observation}

From the above correlational matrix, in the stated variables, it could be interpreted that:

Organizational Head Count (OrgHeadC) has a strong correlation, Human Resource Department Headcount (HRHeadC); at 0.758 index, at a significance value of $1 \%$ (i.e. $p$ value of 0.001 ). This goes to say that ideally there should be a 75 per cent reciprocal effect of these two variables on each other. Hence, we could infer that with increase in organizational headcount, there shall be / should be a reciprocal enhancement in Human Resource Professionals in the organization; and vice-versa.

The current correlation matrix also indicates that the Technical Human Resource Skills go hand-in-hand with Professional HR Capabilities, at an index of 0.883 , at a significance of $1 \%$ ( $p$-value $=0.000$ ). This indicates that the two HR Capabilities / Skills are mutually complementary. This may infer, that individuals with Technical HR Capabilities, necessarily has / may gain, Professional HR Capabilities. But, before such generalizations, a more extensive and aggressive research projects have to be undertaken;

Strategic HR Capabilities propels a strong relationship with Technical HR Capabilities, at a Pearson Correlation Index of 0.806 , at a significance of $1 \%(p$-value $=0.001)$. Further, the current sample indicates, a strong correlation between Business HR Capabilities and Technical HR Capabilities, at a Pearson index of 0.782 , and at a significance of $1 \%$ ( $p$-value $=$ 0.001). Strategic HR Capabilities and Professional HR Capabilities are found to exert strong correlation on each other, to the magnitude of Pearson correlation of 0.704 at the significance of 5\%; and further Professional HR Capabilities on Business HR Capabilities of the organization, at correlation indices of 0.753 at $5 \%$ with a p-value of 0.002 . Finally Strategic Capabilities find correlation with Business Capabilities at a significance level of $10 \%$, with a Pearson Correlation Index of 0.681 at a pvalue of 0.007 . 
The Matrix does not show any other significant correlation elsewhere, at the prescribed significance level. The current study and the presented matrix indicates, a stronger correlation only in seven aspects, upto a significance level of $10 \%$; which is taken to be a fair indicator for the current nature of study.

Hence, the null hypothesis is rejected and the alternate hypothesis: "Prevalence of human resource accounting practices has strong correlation with the ratio of HR professionals to the headcount of an organization" is accepted for the current study.

Table 3: Regression Statistics

\begin{tabular}{|c|l|c|c|c|c|}
\hline Hyp & Explanatory / Predictor Variable & $\begin{array}{c}\text { Expected } \\
\text { Relationship }\end{array}$ & $\begin{array}{c}\text { 8-value } \\
\text { Regression Coefficient }\end{array}$ & SE Coeff & $p$-value \\
\hline \multirow{5}{*}{$\mathrm{H}_{2}$} & Skill Set & Positive & 0.706694 & 0.054520 & $0.002^{*}$ \\
\cline { 2 - 6 } & HR Expenses Reporting & Positive & 4.55018 & 0.010250 & $0.000^{*}$ \\
\cline { 2 - 6 } & Awareness & Positive & -1.51311 & 0.558800 & 0.007 \\
\cline { 2 - 6 } & HRA in India & Positive & 0.0288416 & 0.334350 & 0.931 \\
\cline { 2 - 6 } & Accounting Standards & Positive & -0.0848207 & 0.404719 & 0.834 \\
\cline { 2 - 6 } & HR Domains & Negative & -3.52037 & 0.106447 & $0.001^{*}$ \\
\hline
\end{tabular}

The Regression Output affirms a significant, positive relation between the exogenous variable of HRA Acceptance in Organization, with two endogenous variables - HRA Awareness and Acceptance of HRA across all Human Resource Domains,

The Regression output does not much indicate about the other four variables considered in ascertaining the model,

The strength of association between these three variables is significant and positive;

Therefore, the null hypothesis $\mathrm{H} 10$ is rejected, and the alternative Hypothesis $\mathrm{H} 2$ "Prevalence of human resource accounting practices exhibits relationship with the business skill-set in the human resource departments, is accepted

\section{DISCUSSION}

The study looks at the prevalence of human resource accounting as part of the contextual setting, specifically for the largescale industries. Arguably all of the applied psychological research focused on the individual job performance and is doctrine to influence the performance of an organization; substratum of which is the resource-based theory. The current study reflects that the quantum of human resource should reflect a commensurate increase in the headcount at the human resource departments; which may act as a ready-reckoner for corporates to understand the significance of human resource to the organizations; and the ratio to which the departments should tune their skills for to balance with their manpower.

Because the study statistically aggregates the relevant elements of human resource accounting; the research indicates the significane of quantum of resources to the progress and their skill-sets as an inventory for the organization; thereby indicating human resources as an asset to the organization.

\section{CONCLUSION}

Overall, the study progresses a better understanding on the extent of prevalence of human resource accounting practices in an organization. As an emerging economy, India becomes increasingly knowledge-based, the acquisition and extending skillsets to the organizations' peoples' department is attracting momentum. It appears essential for firms to monitor the headcount and tune it to reciprocal response from the peoples' department; besides equipping the human resource personnel with the necessary skill-sets. For practitioners, the study renders an indicative index to modulate the human resources and the skill-sets of their people. For researchers, the results suggest that resource-based theory is of vital significane to the fundamental structure of human resource accounting; and in particular the specific skill-sets as key determinants for organizational sustainability and human-resource merit. This study may act as a foundation for future studies in India, with respect to quantum of human resources and their reciprocal effect from organization. 


\section{REFERENCES}

Acedo, F. J., Barroso, C., \& Galan, J. L. (2006). The resource-based theory: Dissemination and main trends. Strategic Management Journal , $27,215-239$.

Arnold, D. J., \& Quelch, J. A. (1998). New strategies in Emerging Economies. Sloan Management Review , 40 (1), 7-20.

Barney, J. (1991). Firm resources and sustained competitive advantage. Journal of Management, 17, 99-120.

Barney, J. (2001). Resource-based theories of competitive advantage: A ten-year retrospective on the resource-based view. Journal of Management , 643-650.

Barney, J., \& Arikan, A. (2001). Resource-based view: Origins and implications. (M. Hitt, R. Freeman, \& J. Harrison, Eds.) Malden, MA, USA: Blackwell.

Becker, B., Huselid, M., \& Ulrich, D. (2001). The HR Scorecard: Linking People, Strategy \& Performance. Boston, MA, USA: Harvard Business School.

Brummet, L., Falmholtz, E., \& Pyle, W. (1969). Human Resource Accounting: Development \& Implementation in Industry. Ann Arbor: Foundation for Research on Human Behavior.

Coff, R. W. (1997). Human Assets and Management Dilemmas Coping with Hazards on the Road to Resource-based Theory. Academy of Management Review , 374-402.

Edvinsson, L., \& Malone, M. (1997). Intellectual Capital: Realizing Your Company's True Value by Finding its Hidden Brain Power. New York, NY: Harper Collins.

Gong, Y., Law, K. S., Chang, S., \& Xin, K. R. (2009). Human resources management and firm performance: The differential role of managerial, affective and continuance committment. Journal of Applied Psychology , 94, 263-275.

Grant, R. M. (1996). Prospering in dynamically competitive environments: Organizational capability as knowledge integration. Organizational Science , 375-387.

Grant, R. M. (1991). The resource-based theory of competitive advantage: Implications for strategy formulation. California Management Review , 33, 114-136.

Huselid, M. A. (1995). The Impact of Human Resource Management Practices on Turnover, Productivity \& Corporate Financial Performance. Academy of Management Journal , 635-672.

Israel, G. D. (1992, November). Determining Sample Size. Fact Sheet PEOD-6, a series of the Program Evaluation and Organizational Development, 1-5.

Kaplan, R. S., \& Norton, D. P. (1996). The Balanced Scorecard. Harvard Business School Press.

Kashive, N. (2013). Importance of human resource accounting practices and implications of measuring value of Human Capital: Case Study of successful PSUs in India. Journal of Case Research , 113-144.

Kaur, S., Venkat Raman, A., \& Singhania, M. (2014). Human Resource Accounting Disclosure Practices in Indian Companies. Vision , 217235.

Kogut, B., \& Zander, U. (1992). Knowledge of the firm, combinative, capabilities and the replication of technology. Organization Science , 3, 383-397.

Likert, R. (1967). The Human Organization: Its Management and Value. New York: McGraw - Hill Book Company.

Morrow, S. (1996). Football Players as Human Assets: Measurement as a critical factor in Asset Recognition: A Case Study Investigation. Journal of Human Resource Costing \& Accounting , 1 (1), 75-97.

Narayanankutty, M. (2012). The role of human resource accounting in human resource management. Retrieved October 19 , 2015, from Scribd: http://www.scribd.com/doc/59606063/Oh-20

O'Regan, P., O'Donell, D., Kennedy, T., Bontis, N., \& Cleary, P. (2001). Perceptions of Intellectual Capital: Irish Evidence. Journal of Human Resource Costing \& Accounting , 6 (2), 29-38.

Patra, R., \& Khatik, S. K. (2003). Human resource accounting policies and practices: A case study of Bharat Heavy Electronics Limited, Bhopal, India. International Journal of Human Resource Development and Management , 3 (4), 285-295.

Penrose, E. (1959). The theory of the growth of the firm. White Plains, NY: Sharpe.

Sandervang, A. (2000). From learning to practical use \& visible returns: A Case in Competence Development from a Norwegian Firm. Journal of Human Resource Costing \& Accounting , 1 (2), 82-100.

Sonara, C. K. (2009). Valuation and reporting practices of Human Resource Accounting in India. Journal of Indian Management and Strategy , 14 (3), 47-52. 
Subbarao, A. V., \& Zehgal, D. (1997). Human Resources Information \& Disclosure in Annual Reports: An INternational Comparison. Journal of Human Resource Costing \& Accounting , 2 (2), 53-73.

Sveiby, K. B. (1997). The Intangibles Asset Monitor. Journal of Human Resource Costing \& Accounting , 2 (1), 73-97.

Sveiby, K. E. (1997). The New Organizational Wealth: Managing and Measuring Knowledge based Assets. San Francisco, CA, United States of America: Berrett Koehler.

Takeuchi, R., Lepak, D. P., Wang, H., \& Takeuchi, K. (2007). An empirical examination of the mechanisms mediating between highperformance work systems and the performance of Japanese organizations. Journal of Applied Pyschology , 1069-1083.

Tatiana, A., \& Tatiana, G. (2000). Do all elements of intellectual capital matter for organizational performance? Evidence from Russian context. Journal of Intellectual Capital , 397-412.

Telia, A. B. (1996). The Statement of Human Resources. Journal of Human Resource Costing \& Accounting , 1 (1), 99-116.

Vuontisjarvi, T. (2006). Corporate Social Reporting in the European Context and Human Resource Disclosures: An Analysis of Finnish Companies. Journal of Business Ethics, 331-352. 